\title{
THE MEANING OF LAW AS INSTRUMENT*
}

\author{
by
}

\section{HANNEKE VAN SCHOOTEN \\ University of Twente}

\section{Introduction}

\subsection{Regulation Issues}

The welfare state is based on a system of redistribution of income. Redistribution is realized by goal-oriented law that intervenes in economic and social processes. In comparison with the liberal Rechtsstaat of the nineteenth century, in the welfare state the function of law has fundamentally changed. Instead of codifying existing social norms, law is used to modify society. ${ }^{1}$ This steering mechanism ("law as social engineering") runs up against limits of feasibility. An ongoing process of juridification of social processes has led to a continuing growth in regulation. This "flood of regulations" is increasingly inconsistent and ineffective. It is generally recognized that goal-oriented regulations have unintended side effects. The inadequacy of law as an instrument has become a subject of reflection and discussion. ${ }^{2}$

\subsection{Explanatory Models}

Theoretical models have been constructed to make the problems of instrumental law explicit. Günther Teubner applies the idea of autopoiesis to the law; law and society are two reciprocally closed

* I am grateful to Dick W.P. Ruiter for his inspiring comments on earlier drafts.

1 T. Koopmans, "De rol van de wetgever", in G.E. Langemeijer, ed., Honderd jaar rechtsleven (Zwolle: Tjeenk Willink, 1970), 221-235.

2 "Eindrapport" Commissie Vermindering en vereenvoudiging van overheidsregulering (Den Haag, 1983); "Rapport Rechtshandhaving", Wetenschappelijke Raad voor het Regeringsbeleid (Den Haag, 1988); "Orde in regelgeving", Commissie Wetgevingsvraagstukken (Den Haag, 1985). 
systems. In this option, they do not influence each other directly. ${ }^{3}$ Adam Podgórecki constructs a linear filter-model: the meaning of a legal norm changes in the process of its application. The legal norm passes through three stages: the micro, meso and macro levels in society. ${ }^{4}$ These models emphasize the transformation legal meaning undergoes when confronted with social structures. But what, exactly, is the meaning of "legal meaning"; how is it formed and transformed?

\subsection{Meaning and Law}

This paper concentrates on the concept of meaning in connection with law. Instrumental law includes two different types of meaning. The formal meaning of law expresses legitimacy. It serves to realize the principles of the Rechtsstaat in formal procedures of legislation. The material meaning of law consists of its message, expressed by linguistic signs and aimed at influencing individual behaviour. This second meaning will be analysed on the basis of the theory of knowledge and the concept of action of Jan Glastra van Loon, as well as the semiotics of Charles Sanders Peirce. With the aid of a pragmatic conception of meaning, conclusions will be formulated bearing on the instrumental function of law.

\section{The Process of Formation of Meaning: Glastra van Loon}

\subsection{Gaps}

Although the afore-mentioned models of the transformation of legal meaning by Podgórecki and Teubner purport to provide an account of problems of governmental steering through law, in both models it remains unclear what "meaning" exactly is. I shall give the beginning of an answer to the following questions: how does the formation of meaning take place and what processes of transformation of meaning

3 G. Teubner, Recht als autopoietisches System (Frankfurt am Main: Suhrkamp, 1989); G. Teubner, "Gesellschaftsordnung durch Gesetzgebungslärm?" Jahrbuch fiir Rechtssoziologie und Rechtstheorie 13 (1988), 46.

4 Adam Podgórecki, "Dreistufen-Hypothese über die Wirksamkeit des Rechts", in E. Hirch und M. Rehbinder, eds., Studien und Materien zur Rechtssoziologie (Köln: Westdeutscher Verlag, 1967), 271. 
follow? With the use of the concept of action proposed by Glastra van Loon, in connection with Peirce's semiotics, I will try to clarify how the meaning of law is connected with actions and habits.

\subsection{Acquiring Knowledge by Acting}

Possession of sufficient knowledge enables humans to survive and to cope with their surroundings, their fellow humans included.

Knowledge is not isolated and intrinsically valuable, but something we need to lead a meaningful life as rational creatures. ${ }^{5}$

The knowing agent (subject) and the object of knowledge are opposed to one another. The question of the relationship between subject and object - with regard to knowledge - has fascinated philosophers for centuries. On one side, there is the point of view that knowledge attaches exclusively to the object of knowledge that is awaiting to be discovered (Aristotle). On the other, we are confronted with the idea that knowledge is a faculty of the mind of the knowing subject (Kant). Glastra van Loon takes an intermediary position: knowledge is created in the context of the relation between subject and object that results from the former's actions concerning the latter.

Laws of nature are not regularities of nature an sich, (...) but statements about regularities in nature's response to regular conduct of its investigators. Therefore, they are neither "universalia in re", nor "universalia in mente", they exist in the relation between the conduct of investigating subjects and objective reality. Thus, they have a foundation "in re", as well as "in mente".

The term "knowledge-acquisition" suggests a flow from the object to the subject. By contrast, the term "ascription of meaning" suggests a flow in the opposite direction. In Glastra van Loon's opinion, however, knowledge results from the interaction of both flows. Acquiring knowledge is inextricably connected with processes of meaningascription.

In a learning-process consisting in a sequence of actions, the subject ascribes a subjective meaning to his sensory perceptions of the object. This meaning is tested in further actions: the initially ascribed meaning

5 J.F. Glastra van Loon, "Charles Peirce over het werkelijke", Wijsgerig perspectief $27 / 7 \mathrm{nr} .3$ (1986), 76.

6 Glastra van Loon, supra n.5, at 80. 
is then either found to be a sound one, or rejected as inadequate. In this way, the individual obtains knowledge of the surrounding world by trial and error: by means of the constirutive role of acting, human action becomes a key concept in the development of knowledge, i.e. meaning.

Glastra van Loon's theory of knowledge concerns the relation between subject and object. The theory, however, can also be applied to the interaction between two subjects. With respect to the relation between two subjects, Glastra van Loon describes the way in which knowledge is acquired by subdividing human acts into the following stages.

1. The act is a sign for others.

2. It is connected with preceding perceptions.

3. A perception is an active re-arrangement of perceived elements.

4. This active re-arrangement constitutes (the foundation of) the observer's act-design.

5. The act-design determines the execution of the act.

6. The executed act itself is in its turn a sign for others. ${ }^{7}$

In the following subsections these stages will be examined in turn.

\subsubsection{Act as Sign}

One of the basic necessities of research is the ability to distinguish between one's own actions and the events and actions that take place in the surrounding world. However, the confusing thing about actions is that they can be known - depending on the point of view - both as an objective event by the observer, and at the same time as a subjective performance by the actor himself. The execution of an act is known by the actor as immediate knowledge without the mediation of the senses. For the observer, however, an act is an event exclusively known by the senses. From the observer's viewpoint we turn to the next stage.

\subsubsection{Act Connected with Perceptions}

An observed act cannot be fully understood from a purely external

7 J.F. Glastra van Loon, Norm en handeling (Groningen: Wolters-Noordhoff, 1987), 49-84. 
point of view. A physiological description of an act in terms of musclecontractions in space and time disregards the meaning of the act. This meaning is given by the observer and is co-determined by the relation of the observed act to other acts and by the scene of the act. In other words, the context of the act determines the meaning (see 2.2.3):

Acts must be understood in the meaning they have in their relations to other acts, and for that purpose it is necessary that one comes to know that meaning by a process of (actual or virtual) interacring. ${ }^{8}$

\subsubsection{Perception as Re-arrangement}

Perception is not a passive registration by our senses, but an active rearrangement of perceived events. The perception consists of a set of primary elements, that undergoes a processing by the observer, in which the primary elements are interpreted, i.e. re-arranged into a new composition. In Glastra's terminology this re-arrangement is the "individualizing of the perceived". By the re-arrangement the perception is shaped to what could be called the content.

A perception is only a perception as far as it is individualized, that is, if it is no longer a perception, but a perceptive quality of something $[. ..] .{ }^{9}$

In the individualizing of the perceived, i.e. the re-arrangement of elements, meaning-ascription takes place. The image has become a content; the substance a form. ${ }^{10}$

\subsubsection{Re-arrangement Constitutes the Observer's Act-design}

The new composition in which the elements are re-arranged contains the meaning ascribed by the observer to the perceived act. The re-arranged elements have an indicative function for the way the observer gives shape to his responding act. They form (together) the basis (and the point of departure) for the observer to construct his action in response.

8 Glastra van Loon, supra n.7, at 8.

9 Glastra van Loon, supra n.7, at 52.

10 Glastra van Loon, supra n.7, at 78. 


\subsubsection{Internal Act-design Determines Act-execution}

The re-arranged elements of the observed act are the determinants of a new responding act-design. This act-design manifests itself in its execution. The execution of the act has thus become the externalization of an internal design-process. At the moment of the execution of the act-design the viewpoint changes. The observer has become an actor, executing in turn a (new) act-sign, meant to be observed by others.

\subsubsection{Executed Act as a Responding Sign}

The executed act is a new sign for others. A sign that takes part, in its turn, in a similar process of meaning-ascription as was described before: the act is conceived of as a sign by the observer, which offers possibilities for new acts.

\subsection{Conclusion}

Knowledge is neither exclusively attached to the object (in this case human acts), nor solely a faculty of the observer's mind, but exists in the interaction between object (act) and subject. The act as a sign becomes a key concept. Act and perception are interwoven. A meaning is attributed to the perceived act by a re-arrangement of the perception: the re-arrangement constitutes the act-design that becomes manifest in its execution. This execution is in turn a sign for others. In this way, meaning is continuously developed in a learning-process that takes place by acting.

In brief, the act is constitutive of knowledge. ${ }^{11}$

\section{From Act as Sign to Language as Sign: Mead}

Before switching from Glastra van Loon's ideas to those put forward by Peirce, we must find a way to proceed from Glastra van Loon's notion of acts as signs to Peirce's notion of language as a sign. The pragmaticist George Herbert Mead can serve as an intermediary. In Mind, Self and Society, Mead explains how, starting with unreflective gestural interactions between two individuals (for instance boxers), a new

11 Glastra van Loon, supra n.7, at 243. 
stage can be attained in which gestures are no longer unreflective, but rest on pre-established ideas and meanings. ${ }^{12}$ An example is a fist a person raises in anger against another person. Both know the sign's meaning, without it being necessary that the action expressing the sign leads to an actual fight.

The emergence of gestures as "significant symbols" is only possible if a gesticulating person $A$ is aware of the meaning of his gesture and the other party, $\mathrm{B}$, also knows that $\mathrm{A}$ is aware of that meaning. This mutual awareness of the meaning of a gesture is a consequence of man's ability to grasp the attitude others take towards his own gestures. Mead calls this ability "rôle-taking".

The taking of the attitude of the other toward one's self, or toward one's own behaviour. ${ }^{13}$

Once it is separated from its original action-context, a gesture as a "significant symbol" referring to an idea or meaning - like a raised fist as a symbol for anger - can become an independent sign. Here we can speak of the beginning of abstract "language". In this way, the connection between acts as signs and language as a sign is clarified. Now we can turn our attention to the semiotics of Peirce.

\section{The Semiotics of Peirce}

\subsection{Sign as language-sign}

In this article, Peirce's general definition of the sign-concept is applied to language-signs. Peirce defines semiotics or, in his own terms, "semiosis", as:

... an action or influence, which is, or involves, a cooperation of three subjects, such as a sign, its object and its interpretant. ${ }^{1 / 4}$

The dynamics in Peirce's semiosis can be recognized in his opinion that signs are something alive. A sign is:

something which stands to somebody for something in some respect or

12 G.H. Mead, Mind, Self and Society (Chicago: University of Chicago Press, 1962), $42-51$.

13 Mead, supra n.12, at 48.

14 C.S. Peirce, Collected Papers (Cambridge Mass.: Belknap Press of Harvard University Press, 1931), 5.484. 
capacity,

And:

It addresses somebody, that is creates in the mind of that person an equivalent sign, or perhaps a more developed sign. ${ }^{15}$

Sign, object and interpretant are arranged in the form of a triangle: the basis connects sign and object. At the top of the triangle the interpretant of this sign has its place. The interpretant is a further developed form of the original sign.

Under "object", Peirce classifies things, events and actions. Here I shall only concentrate on actions. By "sign" I understand the languagesigns corresponding with the actions: names and terms that refer to the actions. In the interpretant, the language-sign finally develops into a new language-sign. This development of signs in the interpretant takes place by acting.

\subsection{Interpretation: Meaning-formation by Acting}

The dynamic process in which every further interpretant forms a new version of the preceding sign causes an evolution of signs. From an initial sign there emerges - in the interpretant - a new sign, from which emerges yet another sign and so on and so forth.

This spiral of meaning-formation is instigated by the interpretation of perceived acts, followed by an internal design process for responding acts that becomes manifest in the execution of the act. The latter act is in turn a new sign for interpretation and acting. No act of interpretation is ever final. So in Peirce's view, interpretation does not take place exclusively in the mind. Our thinking is continuously influenced by facts that force themselves upon us in the shape of our acting experience. New facts emerge from responding and testing acts and form - when evaluated - new premises in our thinking. The essence of pragmaticism rests in this connection between thinking and acting. In Peirce's view, no utterance is true "unless it has effects that might conceivably have practical bearings".

The internal process of interpretation, externally tested and evaluated by acting, analysed in Glastra van Loon's concept of action, fits well with the process of meaning-formation, which Peirce 
differentiates in three stages: abduction, deduction and induction. Peirce extends the existing forms of reasoning - deduction and induction - with a third form: abduction. As a result of this extension, and the manner in which Peirce puts the three forms in sequence, the forms of deduction and induction not only acquire a different meaning, but are also rendered "dynamic". Peirce describes the sequence of the three stages as a learning-process by acting in the following way. Abduction is "the process of forming an explanatory hypothesis" 16 about the experienced facts. Deduction is the process of making explicit the expectations (expected consequences) following from the hypothesis. Induction is the process of confronting the expectations emerging from the formulated hypothesis with reality. This testing takes place by acting. Such processes of abduction, deduction and induction yield consistent act-patterns: habits.

That a habit is a rule active in us, is evident. ${ }^{17}$

We need habits in our everyday life to deal with our environment in an efficient way.

\subsection{Semiosis and the Concept of Action}

Peirce's semiosis is concerned with the formation of the meanings of signs by way of interpretation. The process of interpretation associates thinking with acting. This is the same process of knowledge-acquisition we already found in Glastra van Loon's concept of action. The six stages of Glastra van Loon's act-concept form an analytic division of something that presents itself as a unity in reality. The different stages of the act concept partly overlap. For instance, an act as a sign (stage 1 and 6) is always connected with preceding and simultaneous perceptions (stage 2 ), the constitution of an act-design and the act-design itself are interwoven. Therefore it is difficult to fit Glastra van Loon's stages of the act-concept exactly into Peirce's three categories. Nevertheless, the similarity is striking:

16 Peirce, supra n.14, at 5.171.

17 Peirce, supra n.14, at 2.643 . 


\begin{tabular}{|c|c|}
\hline Glastra van Loon & Peirce \\
\hline 1. act as sign & \multirow{3}{*}{$\begin{array}{c}1+2+3 \text { abduction: searching } \\
\text { process for a } \\
\text { hypothesis }\end{array}$} \\
\hline 2. perceptions & \\
\hline 3. active re-arrangement & \\
\hline 4. constitutes act-design & \multirow{2}{*}{$\begin{array}{l}\text { deduction: formation } \\
\text { and formulation } \\
\text { of the hypothesis }\end{array}$} \\
\hline $\begin{array}{l}\text { 5. constitutes } \\
\text { act-execution }\end{array}$ & \\
\hline $\begin{array}{l}\text { 6. executed act } \\
\text { as a sign }\end{array}$ & $\begin{array}{l}\text { induction: testing } \\
\text { of hypothesis by } \\
\text { acting }\end{array}$ \\
\hline
\end{tabular}

In Glastra van Loon's concept of action, the act is a sign for others, perceived by the senses (stages 1 and 2). These two stages correspond to the abduction phase of Peirce's interpretation-process. The perception of a sign (act) is a necessary condition for the initiation of the process of abduction. In Glastra van Loon's view, perception is never a passive registration but an active re-arrangement through which a meaning is ascribed to the perceived act (stage 3 ). This stage also corresponds to the searching process that becomes effective during the ensuing phase of abduction necessary for finding a hypothesis.

Glastra van Loon's view of the active re-arrangement (i.e. meaning ascription) of that which has been perceived, constitutes the design of an intended act (stages 4 and 5). This internal design-process for intended actions coincides with Peirce's formulation of a hypothesis by the observer: the deduction phase. The formulation of a hypothesis includes expectations: the calculation of the effects caused by the intended act.

The execution of the act-design (stage 6) corresponds with Peirce's induction-phase, in which the formulated expectations of the hypothesis about the perceived act is tested by a responding act, executed by the observer. 
The observer has become an actor now. The new testing act is in turn a sign for others (stages 6 and 1). The other perceives the executed act and ascribes a temporary meaning by actively re-arranging that which is perceived (abduction); he designs an act in response (deduction) and executes the intended act in order to test his expectations (induction).

In the interaction between two persons, the act of each one is a sign for the other. The interpreted expectation about effects is tested by responding acts and is either confirmed or not. In this way consistent act-patterns gradually arise: habits.

\subsection{Legal Rules and Rules of Habit}

The foregoing comparison between Peirce's semiotics, his theory of abduction and Glastra van Loon's concept of action, clarifies their common implicit notion of the rationality of practical knowledge which guides action. The dynamic process of interpretation, as described above, illuminates how the forming of the meaning of signs is connected with the continuous process of thinking, acting and testing. The process, however, cannot go on infinitely. It terminates at the (temporary) "final interpretant": the habit. A habit is a rule that emerges from the interpretation of (action) signs. But the rule, expressed by the habit, is never fixed, because there always remains the possibility of an unpredicted occurrence: the expected act-consequences can be falsified.

Social rules laid down in habits and action-patterns are thus presented as predominant over instrumental "black letter" law. It is in confrontation with these action-patterns that the meaning of legal rules is formed and established. With respect to the law, the conclusion is justified that law receives its final meaning from its efficacy.

Illustrative of this conclusion is a study by the legal anthropologist Sally Falk Moore of the relations and mutual influence of formal law with those habits and action-patterns that are creative of informal law.

\section{Moore's Social Fields ${ }^{18}$}

Moore investigates the interplay between formal and informal law that takes place in so-called "semi autonomous social fields" (SASF). an appropriate subject of study", Law and Society Review 7 (1973), 719-746. 
She discusses the steering-conception of law, in which legal rules are considered to determine the conduct of social groups. Moore agrees with Max Weber where he recognizes certain problems connected with the execution of legal sanctions.

In an economy based on all-embracing interdependence on the market, the possible and unintended repercussions of a legal measure must to a large extent escape the foresight of the legislator, simply because they depend upon private interested parties. It is those private interested parties who are in a position to distort the intended meaning of a legal norm to the point of turning it into its very opposite, as often happened in the past. ${ }^{19}$

The distinguishing feature of SASF's is that they comprise a group of individuals in mutually coordinated positions who pursue a common objective in particular social circumstances, and prove capable of producing and maintaining their own regulations. The demarcation may coincide with the boundaries of some organizational unit, but this is not necessary. The social field can be characterized as an arena of interaction under the same self-regulating device. A number of SASF's may merge into a new SASF. Structures and processes of this kind are characteristic of our modern complex society.

The degree of autonomy of a social field depends on the strength of its self-regulating action-patterns. New regulations result from a variety of individual acts and choices that develop into new habits. One of the usual ways in which Western states intervene in social fields is by means of the law. However, legal norms that are meant to steer social processes quite often fail to achieve that purpose or have unintended and unexpected side-effects because they disturb social structures based on existent habits and rules.

The degree of autonomy of self-regulation determines the group's power to resist external attempts at legal engineering. In this way, groups determine to a considerable extent the meaning of the law.

Moore's model is one of interaction between steering law on the one hand and self-regulating habits and rules on the other. The original steering-idea, according to which legal rules determine social conduct, is in Moore's view replaced by a view in which social conduct determines legal rules. Moore has tested her view in two case-studies. The first is a case-study about the clothing industry in New York; the second is

19 Max Weber, Law in Economy and Society (Cambridge Mass.: Harvard University Press, 1954), 18-19. 
concerned with the Chagga-tribe of the Kilimanjaro. The first casestudy will be described in the next section.

\subsection{Clothing Industry in New York: SASF}

Moore investigates the New York clothing industry as a semiautonomous social field. In this field, designers, contractors and labourers maintain interdependent and flexible relations based on contract and habits. Legal regulation enters this field in the form of provisions concerning working hours and wages.

The clothing industry is subject to fashion and seasonal change. Whereas in busy times there is more work than can be handled, in stagnant periods there is insufficient work to keep the business going. Legally speaking, in both kinds of periods legal rules concerning working hours and wages have to be observed. A trade-union agent is charged with the supervision. However, circumstances in the clothing industry are such as to make it impossible to comply strictly with legal rules concerning working times and wages and make a profit at the same time. Between the union-agent on the one hand and the contractors and labourers on the other, it is tacitly agreed that the legal rules need not be strictly obeyed. The union agent receives for his "obligingness" gifts of small to considerable value. This procedure can be called "corruption" when one focuses on its illegal character. However, it can also be considered as part of a self-regulating system that has emerged under the pressure of the prevailing circumstances. The degree of autonomy of the social field turns on the strength of the self-regulating mechanism and the resistance the field can put up against intervening legal rules.

There is strong social pressure to conform to this informal system of exchange if one wants to take part in this branch of industry on a permanent basis. Legal rules are only a small part of a whole complex of regulations. If the game is not played according to this complex, sanctions such as exclusion and economic loss will result.

From both rule-types distinguished by Moore - the rules enacted by the legislator and those that emerge "spontaneously" from social processes - the former type is often overrated and the latter underrated. The assumption that legal rules determine social processes is reversible: social processes also determine to a great extent the meaning of the law. 


\section{Conclusion}

This paper started with the problems of legal regulation in modern interventionist states and the increasing ineffectiveness of instrumental law. The theories of Teubner and Podgórecki explain this phenomenon by constructing models that try to expose causes of legal transformation. The models do not provide a satisfactory explanation of what the meaning of instrumental law is and how it is transformed in its application. With the help of the concept of action by Glastra van Loon and Peirce's semiotics I tried to clarify how the meaning of instrumental law is connected with actions and habits. This leads to different consequences from those indicated by Teubner (i.e. law and social fields are two reciprocally closed self-referential systems; direct steering of the latter by the former is not possible) and those indicated by Podgórecki (i.e. law is transformed by the norms that exist within a specific group). Without full elaboration of the consequences of Glastra van Loon's and Peirce's ideas about meaning and law, and without claiming to provide a solution for the regulation crisis, the following points may be formulated. The steering of social fields by means of instrumental law is possible on condition that significant discrepancies between the behaviour prescribed by official legal rules and the rules underlying existing habits should be avoided. Secondly, a minimal degree of acceptance of the goals of instrumental law in the social field is a necessary precondition for the effectiveness of law. Thirdly, in regulating social behaviour by law, specific circumstances in the social field should be taken into account.

This set of conditions indicates the boundaries of the domain in which instrumental law can function more effectively. However, the process of changing patterns of behaviour by formal law is a slow and gradual one, in which it is necessary to take into consideration the existing habits and self-regulating rules generated by the group, because these habits and rules will play an important role in determining the ultimate meaning of the new law. 